\author{
G. Saltanova, T. Aisina \\ Kh.Dosmukhamedov Atyrau State University, Kazakhstan \\ (E-mail: galiyasaltanova@yandex.ru)
}

\title{
Mathematical model of non-isothermal flow of oil through the trunk pipeline
}

\begin{abstract}
In this article are described a non-isothermal current of high-viscosity oil. A non-isothermal current of viscous liquid on the trunk pipeline it is characteristic of transportation of oil and oil products with preliminary heating from places of production to a customer, of a current of hot water from combined heat and power plant to inhabited arrays and production locations, etc. The one-dimensional mathematical model of a non-isothermal current of viscous liquid and a formula of cost fuel - power expenses for the stationary mode of a current are examined. It is spoken in detail the process of calculation of optimum speed of a current for transportation of high-viscosity oil and oil products in the warmed-up state on pipelines at which the total cost of energy costs of pumping and heating of oil would be minimum.
\end{abstract}

Keywords: high-viscosity oil, viscous liquid, non-isothermal current, stationary mode of a current, pipeline, energy expenses, speed of current.

\section{Introduction}

The Kazakhstan oil is considered very viscous, and its transportation in the warmed-up state on pipes requires big energy expenses. On the other hand, the considerable time pipelines work with plan underload. Therefore, the choice of the modes of a current in case of which the cost of pumping will be minimum is very demanded. The purpose of work - to investigate process of non-isothermal flow of high-viscosity oil in the main pipeline and to find such management of process of a flow at which the total cost for power expences of pumping and for heating of oil would be minimum when transporting by the pipelines working with planned under loading [1].

For achieving the purpose it is necessary to solve the following problems:

- to study process of non-isothermal flow of high-viscosity oil in the main pipeline;

- to put and solve the problem of a thermo - hydraulic flow of liquid in the pipeline;

- to estimate the cost of transportation of high-viscosity oil;

- to calculate the optimum speed of a flow of oil at which cost would be minimum.

\section{Basic calculations}

Computation of optimum speed of operation of the underloaded oil pipeline were executed by means of object-oriented programming language $\mathrm{C} \#$.

Calculation of temperature, pressure and energy consumption for operation of the pipeline

Calculation of temperature at an entrance to each site. Calculation of temperature is calculated by means of the following formula

$$
\begin{gathered}
T_{j-1}^{+}=T_{e n v}+\left(T_{j}^{-}-T_{e n v}\right) \cdot e^{\frac{\alpha_{j-1}}{w}} ; \\
T_{j}^{-}=T_{\text {min }}=33^{\circ} \mathrm{C} .
\end{gathered}
$$

For finding of temperatures on sites, it is necessary for us a difference of sites, which they are provided in drawing from above under $L_{j}$ value (Fig. 1) [2].

$$
L_{j}=\left[x_{1}, x_{2}, x_{3}, x_{4}, x_{5}\right]=[145000,177000,111000,95000,213000] \mathrm{km} .
$$




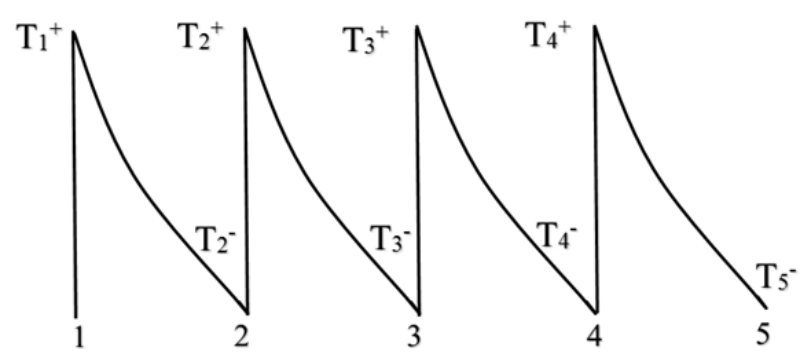

Figure 1. Distribution of temperature along the route of the oil pipeline

Calculation of pressure on an entrance to each site (Fig. 2). Calculation of pressure on an entrance to each site is calculated by means of the following formula

$$
\begin{gathered}
\Delta P_{j}=P_{j}^{+}-P_{j}^{-}=H_{j-1}+E \cdot w^{2-m}\left[A_{j-1}-B_{j-1} \cdot \Delta T_{e n v} \cdot w\left(e^{\frac{\alpha_{j}-1}{w}\left(x_{j-1}-x_{j}\right)}-1\right)\right] ; \\
P_{j}^{-}=P_{\text {min }}=2 a t m .
\end{gathered}
$$
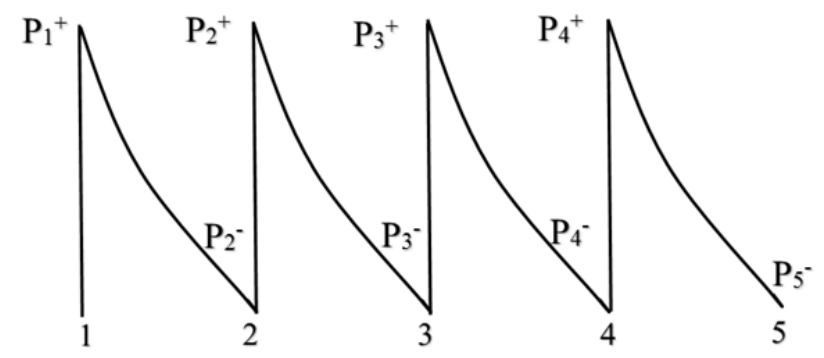

Figure 2. Distribution of pressure along the route of the oil pipeline [2]

Calculation of energy consumption for exploitation of the pipeline. Calculation of cost is calculated by means of the following formula

$$
S=a e \cdot w \cdot \sum_{j=1}^{N} \varphi_{j} \Delta P_{j}+\delta \cdot w \cdot \sum_{j=1}^{N} y_{j} \Delta T_{j} .
$$

Calculation of optimal speed

Calculation of optimal speed is calculated by means of the following formula

$$
\begin{gathered}
w=\delta \cdot \Delta T_{\text {env }} \sum_{j=1}^{N} y_{j} \alpha_{j} \cdot e^{\frac{\alpha_{j-1}}{w}}+\alpha e \cdot E \cdot w^{3-m}\left[(4-m) \cdot \Delta T_{e n v} \cdot w \cdot \sum_{j=1}^{N} y_{j} B_{j}\left(e^{\frac{\alpha_{j-1}}{w}}-1\right)-\right. \\
\left.-(3-m) \sum_{j=1}^{N} y_{j} A_{j}-\Delta T_{e n v} \sum_{j=1}^{N} y_{j} B_{j} \alpha_{j} e^{\frac{\alpha_{j-1}}{w}}\right]: \\
:\left[\alpha e \sum_{j=1}^{N} \varphi_{j} H_{j}+\delta \cdot \Delta T_{e n v} \sum_{j=1}^{N} y_{j}\left(e^{\frac{\alpha_{j-1}}{w}}-1\right)\right] .
\end{gathered}
$$

By means of the found speeds, we find anew temperature, pressure and cost. In which speed, cost will be minimum - it will be optimum speed [3-5].

\section{Results of thermal-hydraulic calculation for different seasons}

Heat hydraulic calculation for spring. For spring temperature surrounding will be $T_{e n v}=10^{\circ} \mathrm{C}$.

In Figure 3 provides the view of interface which gives the results of thermal-hydraulic calculation for spring. 


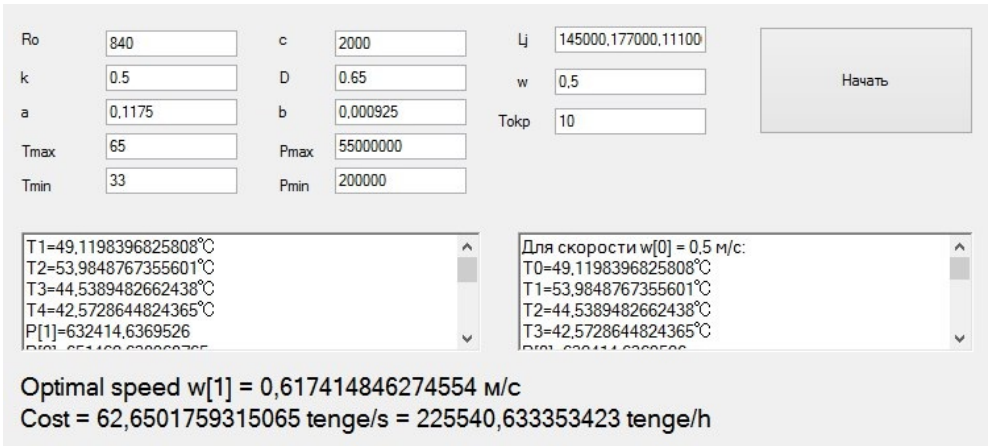

Figure 3. Window of results of thermal-hydraulic calculation for spring

From Figure 4, we can assume that at $w=0,61$ speed, we have the minimum cost. Therefore, for spring it will also be optimum speed.

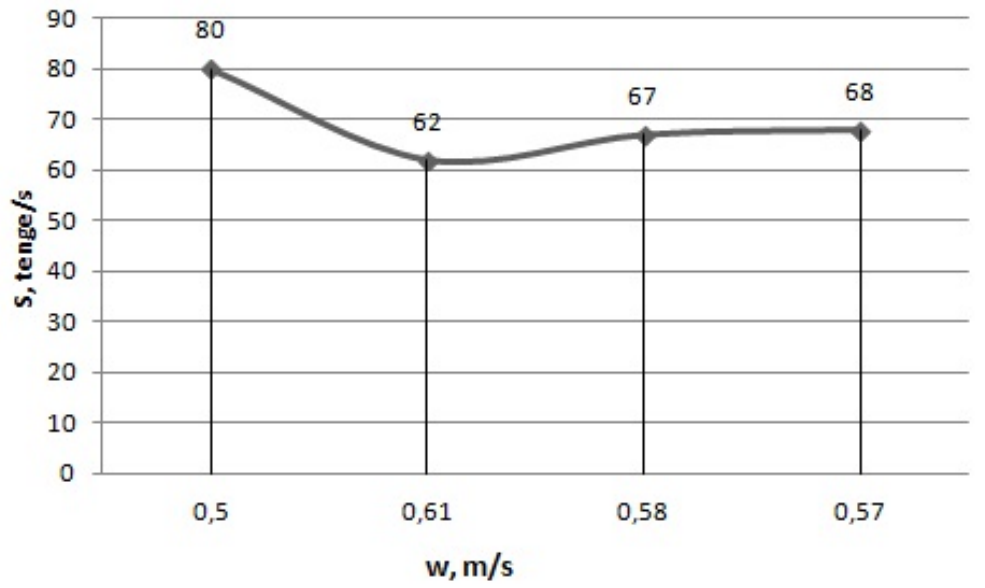

Figure 4. Dependence of working cost of the oil pipeline on speed

Thermal-hydraulic calculation for summer. For summer temperature surrounding will be $T_{e n v}=18^{\circ} \mathrm{C}$.

In Figure 5 provides the view of interface which gives the results of thermal-hydraulic calculation for summer.

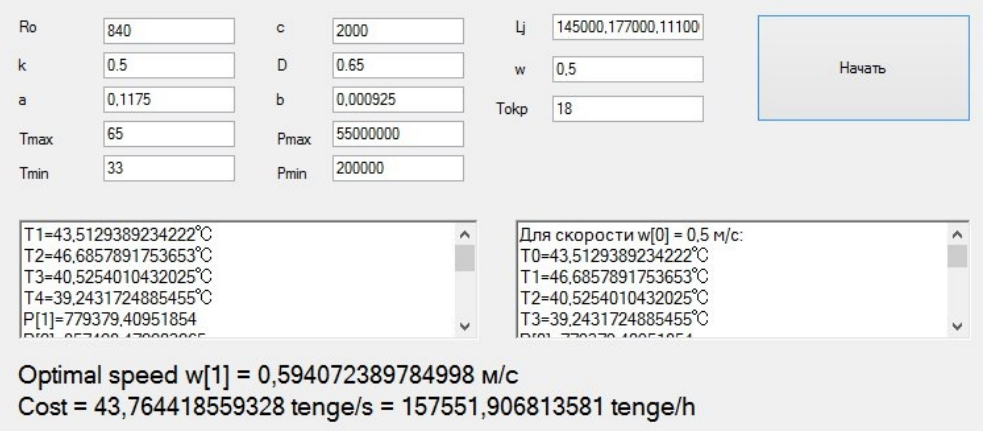

Figure 5. Window of results of thermal-hydraulic calculation for summer

From Figure 6, we can assume that at $w=0,59$ speed, we have the minimum cost. Therefore, for summer it will also be optimum speed.

Thermal-hydraulic calculation for winter.For summer temperature surrounding will be $T_{e n v}=2{ }^{\circ} \mathrm{C}$. 


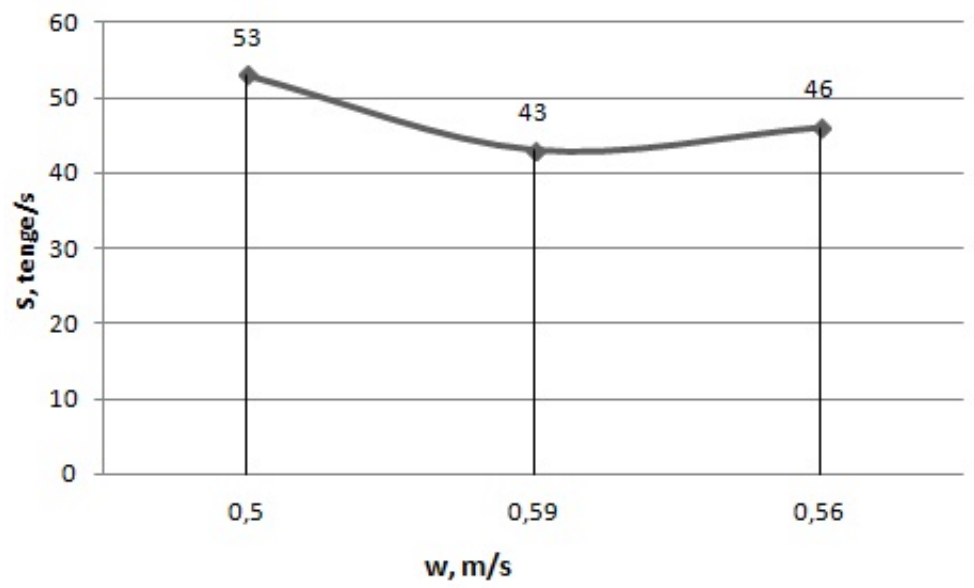

Figure 6. Dependence of working cost of the oil pipeline on speed

In Figure 7 provides the view of interface which gives the results of thermal-hydraulic calculation for winter.

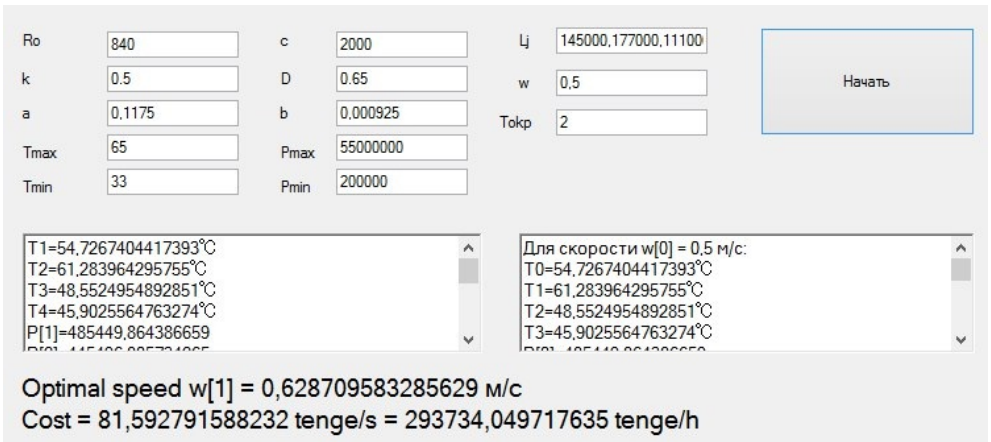

Figure 7. Window of results of thermal-hydraulic calculation for winter

From Figure 8, we can assume that at $w=0,62$ speed, we have the minimum cost. Therefore, for winter it will also be optimum speed.

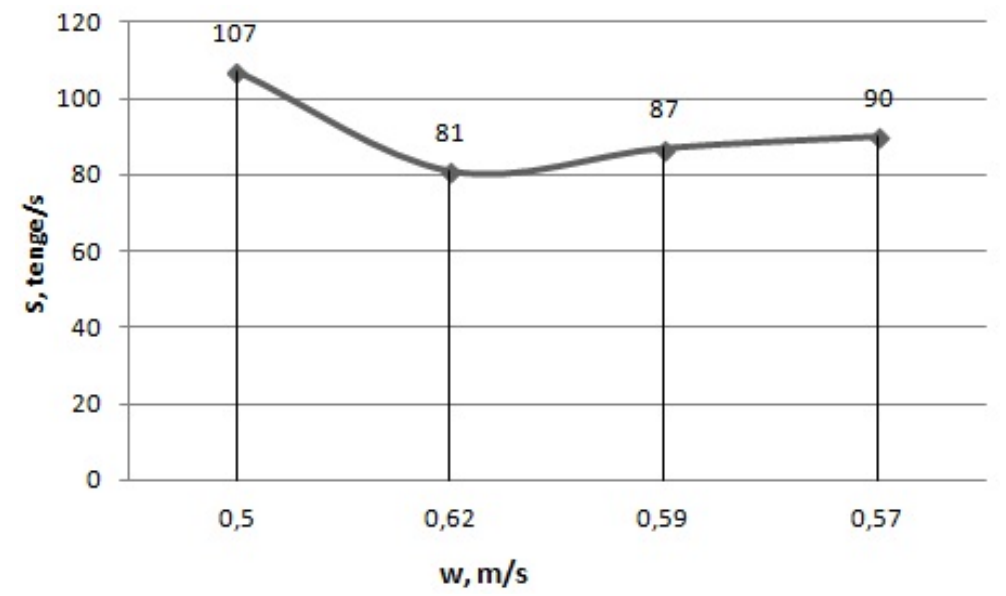

Figure 8. Dependence of working cost of the oil pipeline on speed 
In Figure 9 provide the change of optimum speed at different seasons, i.e. for spring, summer and winter.

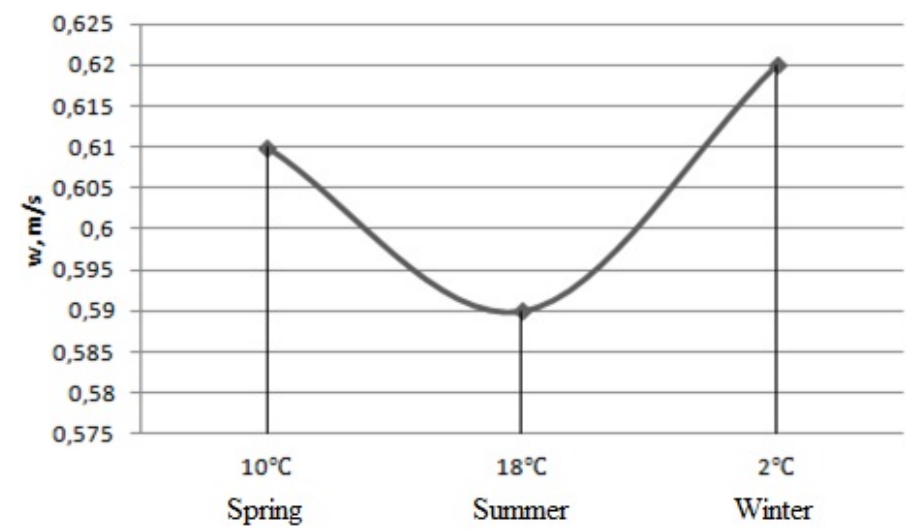

Figure 9. The change of optimum speeds at different seasons

We can assume, in winter that transportation requires more speed than in other two seasons. And respectively, there will be more energy consumption in the winter than in other two [6].

\section{The received results}

As a result of the conducted research, we can draw the following conclusions:

1. Process of transportation of oil through the pipeline is investigated.

2. Not isothermal current of high-viscosity oil is explored.

3. The one-dimensional mathematical model of not isothermal current of viscous liquid is investigated.

4. Calculation of temperature and pressure for different speeds of a current of oil with estimation of cost is executed.

5. The technique of obtaining optimum speed of a current of oil at which working costs of the oil pipeline are minimum is developed.

\section{References}

1 Карымсакова Э.С. Развитие трубопроводного транспорта нефти в Республике Казахстан / Э.С. Карымсакова, А.А. Коршак, Э.М. Мовсумзаде. - М.: Химия, 2003. - 192 с.

2 Нестеренкова Л.А. Математическое моделирование нестационарного течения в недогруженном нефтепроводе / Л.А. Нестеренкова, Г.В. Вдовиченко // Вестн. Казахс. ун-та. Сер. матем. - Алма-Ата: КазГУ, 1995. - 85 с.

3 Нестеренкова Л.А. Решение задач в неизотермическом движении нефти в трубопроводе / Л.А. Нестеренкова // Математическое моделиование и оптимальное управление. - Алма-Ата: КазГУ, 1980. 200 c.

4 Нестеренкова Л.А. Теплогидравлический расчет установившегося неизотермического течения нефти в разветвленном нефтепроводе / Л.А. Нестеренкова // Математическое моделирование нестационарных процессов. - Алма-Ата: КазГУ, 1988. - 130 с.

5 Нестеренкова Л.А. Оптимизация неизотермического в течения недогруженном нефтепроводе / Л.А. Нестеренкова, А.Т. Лукьянов // Математическое моделирование явлений переноса. - АлмаАта: КазГУ, 1987. - 65 с.

6 Салтанова Г.А. Математическая модель неизотермического течения вязкой нефти в трубопроводе / Г.А. Салтанова, Т.С. Айсина // Вестн. Атырау. гос. ун-та. - 2016. - № 4(43). - 188 с. 
Г.Салтанова, Т.Айсина

\title{
Мұнайдың магистралды құбыр арқылы изотермиялық емес қозғалысының математикалық моделі
}

\begin{abstract}
Мақалада тұтқырлығы жоғары мұнайдың изотермиялық емес ағыны сипатталған. Магистралдық мұнай құбыры бойынша тұтқыр сұйықтықтың изотермиялық емес ағыны, мұнай мен мұнай өнімдерін өндіру алаңынан тұтынушыға дейін, ЖЭО-нан тұрғын үйлер мен өндірістік нысандарға дейін ыстық су ағымын және тағы басқа тасымалдау үшін тән. Тұтқыр сұйықтықтың изотермиялық емес ағынының бірөлшемді математикалық моделі және тұрақты ағын тәртібіне арналған отын-энергия шығындарын есептеудің негізгі формуласы зерттелді. Тұтқырлығы жоғары мұнай мен мұнай өнімдерін қыздырылған күйінде құбырлар бойынша тасымалдау үшін мұнайды айдауға және жылытуға кететін отын-энергия шығындарының жалпы құны аз болатындай ағынның оңтайлы жылдамдығын есептеу үдерісі толық сипатталған.
\end{abstract}

Kiлm сөздер: тұтқырлығы жоғары мұнай, тұтқыр сұйықтық, изотермиялық емес ағын, ағынның стационарлық тәртібі, құбыр, энергетикалық шығын, ағын жылдамдығы.

\section{Г.Салтанова, Т.Айсина}

\section{Математическая модель неизотермического движения нефти по магистральному трубопроводу}

\begin{abstract}
В статье описано неизотермическое течение высоковязкой нефти. Неизотермическое течение вязкой жидкости по магистральному трубопроводу характерно для транспортировки нефти и нефтепродуктов с предварительным подогревом от мест добычи к потребителю, для течения горячей воды от ТЭЦ до жилых массивов и производственных помещений и т.п. Исследованы одномерная математическая модель неизотермического течения вязкой жидкости и формула стоимости топливно-энергетических затрат для стационарного режима течения. Подробно описан процесс вычисления оптимальной скорости течения для транспортировки высоковязкой нефти и нефтепродуктов в подогретом состоянии по трубопроводам, при котором общая стоимость энергетических затрат на перекачку и подогрев нефти была бы минимальной.
\end{abstract}

Ключевые слова: высоковязкая нефть, вязкая жидкость, неизотермическое течение, стационарный режим течения, трубопровод, энергетические затраты, скорость течения.

\section{References}

1 Karymsakova, E., Korshak, A. \& Movsumzade, E. (2003). Razvitie truboprovodnoho transporta nefti $v$ Respublike Kazakhstan [Development of pipeline transport of oil in the Republic of Kazakhstan]. Moscow: Chemistry [in Russian].

2 Nesterenkova, L. \& Vdovichenko, G. (1995). Matematicheskoe modelirovanie nestatsionarnogo techeniia v nedogruzhennom nefteprovode [Mathematical modeling of a non-stationary current in the underloadedoil pipeline]. Vestnik Kazakhskii universiteta. Seria matematichtskaia - Bulletin of KAZSU. Mathematic series, 85. Alma-Ata: KazHU [in Russian].

3 Nesterenkova, L. (1980). Reshenie zadach $\mathrm{v}$ neizotermicheskom dvizhenii nefti $\mathrm{v}$ truboprovode [The solution of tasks in non-isothermal movement of oil in the pipeline]. Matematicheskoe modeliovanie i optimalnoe upravlenie - Mathematical modeling and optimum control, 200. Alma-Ata: KazHU [in Russian].

4 Nesterenkova, L. (1988). Teplohidravlicheskii raschet ustanovivshehosia neizotermicheskoho techeniia nefti $\mathrm{v}$ razvetvlennom nefteprovode [Thermal-hydraulic calculation of the established non-isothermal current of oil in the branched oil pipeline]. Matematicheskoe modelirovanie nestatsionarnykh protsessov Mathematical modeling of non-stationary processes, 130. Alma-Ata: KazHU [in Russian]. 
5 Nesterenkova, L. \& Lukyanov, A. (1987). Optimizatsiia neizotermicheskogo v techeniia nedohruzhennom nefteprovode [Optimization of non-isothermal current underloaded oil pipeline]. Matematicheskoe modelirovanie iavlenii perenosa - Mathematical modeling of the phenomena of transfer, 65. Alma-Ata: KazHU [in Russian].

6 Saltanova, G. \& Aisina, T. (2016). Matematicheskaia model neizotermicheskoho techeniia viazkoi nefti $\mathrm{v}$ truboprovode [Mathematical model of non-isothermal flow of oil in a pipeline]. Vestnik Atyrauskoho hosudarstvennoho universiteta - Bulletin of the Atyrau State University, 4(43), 188 [in Russian]. 